УДК 378.147-051:793.3

DOI:

Магдалина Марушка, кандидат педагогічних наук, викладач кафедри культурології та мистецької освіти Дрогобицького державного педагогічного університету імені Івана Франка

\title{
МОДЕЛЬ ФАХОВОЇ ПІДГОТОВКИ ВЧИТЕЛІВ ХОРЕОГРАФІЇ НА ОСНОВІ КОМПЕТЕНТНІСНОГО ПІДХОДУ
}

У статті аналізуються аспекти компетентнісного підходу до фахової підготовки здобувачів вищоі освіти хореографічного профілю. Зазначено, щчо завданням компетентнісного підходу є формування професійної компетентності випускника, яка включає фахові знання, вміння і навички, відповідні властивості та якості особистості педагога-хореографа. Розглянуто організаційну модель фахової підготовки вчителів хореографії на основі компетентнісного підходу. Модель враховує усі складові освітнього процесу: мету, завдання, методологічні підходи та дидактичні принципи, педагогічні умови; зміст, форми, методи навчання.

Ключові слова: хореографічна освіта; компетентнісний підхід; професійна компетентність; модель фахової підготовки; навчальний процес.

Puc. 1. Лim. 6.

Magdalyna Marushka, Ph.D.(Pedagogy), Lecturer of the Culturology and Art Education Department, Ivan Franko Drohobych State Pedagogical University

\section{MODEL OF PROFESSIONAL TRAINING OF CHOREOGRAPHY TEACHERS ON THE BASIS OF COMPETENCE APPROACH}

The article is devoted to theoretical and practical aspects of training choreographers based on the competence approach. Competence approach is a relevant and conceptual direction in the higher education system. Competence approach directs innovative strategies in education to address the main goal - the formation of a highly professional specialist capable of self-improvement. It is noted that the organization of the process of training future choreographers involves a theoretical understanding of the problem of formation of basic and subject competencies in students. The professional competence of the future teacher of choreography is an integrated education, which is one of the manifestations of his professional development and professional-pedagogical culture, is an indicator of the formation of professionally necessary qualities and characteristics on the basis of psychological-pedagogical and professional knowledge, skills. Professional competencies determine the readiness to carry out choreographic and pedagogical activities, provide a high level of self-organization and professional self-realization. The article presents a model of professional training of choreography teachers based on the competency approach. The model provides mastering in educational process of special knowledge, practical abilities and skills, development of professionally significant qualities of the personality of the future expert. The organizational model is a set of interdependent components. The model takes into account didactic principles, methodological approaches, pedagogical conditions, methods and forms of organization of the educational process. The result is a multifunctional and professional competence of the choreographer who combines the functions of a teacher-educator, a leader of the choreographic team.

Keywords: choreographic education; competence approach; professional competence; model of professional training; educational process.

П остановка проблеми. В умовах модернізації освіти нові вимоги ставляться і до якості підготовки майбутніх фахівців. Зокрема, випускник спеціальності “Хореографія" має не лише володіти виконавськими танцювальними вміннями, а й знаннями з методики викладання хореографічних дисциплін. Відповідно фахова підготовка майбутніх вчителів хореографії у закладах вищої освіти спрямована на опанування теоретичних знань, розвиток практичних вмінь, засвоєння педагогічних технологій. На сьогоднішній день стандарти педагогічної освіти визначаються на основі професійних компетентностей. Це зумовлює необхідність побудови освітнього процесу у закладах вищої освіти відповідно до компетентнісно-кваліфікаційних вимірів. У цьому контексті пріоритетним методологічним підгрунтям фахової підготовки є компетентнісний підхід.

Аналіз досліджень і публікацій 3 питань фахової підготовки хореографів засвідчив, що компетентнісний підхід $є$ актуальним i концептуальним напрямом у системі вищої освіти. На це вказують праці вітчизняних науковців, присвячені питанням застосування компетентнісного підходу у фаховій підготовці вчителів (М. Головкова, Н. Дзюбишина, А. Коробченко, Т. Медвідь, 


\section{МОДЕЛЬ ФАХОВОЇПІДГОТОВКИ ВЧИТЕЛІВ ХОРЕОГРАФІЇ НАОСНОВІКОМПЕТЕНТНІСНОГОПДХОДУ}

Л. Червонська); теоретичним аспектам підготовки хореографів (Т. Дорошенко, О. Мартиненко, А. Чернишова), проблемамформування компетентностей учителів хореографіївумовахосвітньогопросторузакладів вищоїосвіти(Ю.Тараненко, О. Тіщенко).

Під компетентнісним підходом науковці розуміють “метод моделювання результатів освіти як норм якості вищої освіти. Компетентнісний підхід дозволяє: перейти у вищій освіті від іiї орієнтації на відтворення знання до застосування й організації знання; покласти в основу стратегію підвищення гнучкості на користь розширення можливості працевлаштування; поставити за основу міждисциплінарно-інтегровані вимоги до результату освітнього процесу; орієнтувати діяльність випускників на розмаїтість професійних і життєвих ситуацій. Компетентністний підхід в освіті грунтується, насамперед, на міждисциплінарних інтегрованих вимогах до результату освітнього процесу. Його варто розглядати як методологічну основу забезпечення цілей, змісту та якості освіти" [1, 21-22].

Як “основу підготовки майбутніх фахівців, що передбачає розвиток в особистості здатності орієнтування у розмаїтті складних ситуацій, вміння прогнозувати результати своєї діяльності і нести за них відповідальність” Л. Червонська розглядає компетентісний підхід [6, 268].

А. Коробченко та М. Головкова зазначають, що “для закладу вищої педагогічної освіти компетентнісний підхід повинен означати, що результатом професійної освіти вчителя буде не сума предметно-спеціальних знань і навичок, а його здатність діяти в різних педагогічних ситуаціях. Тому компетентностями випускника закладу вищої педагогічної освіти виступає єдність предметно-професійних знань, що є в нього, засвоєних технологій, здатностей діяти в ситуаціях, що передбачаються в діяльності вчителя" [3, 149].

Наявні дослідження виявляють значимість компетентнісно-орієнтованої підготовки фахівців у вищій школі. Це актуалізує подальший аналіз концептуальних засад, теоретичних та практичних аспектів формування фахових компетентностей майбутніх вчителів хореографії.

Мета статті - проаналізувати організаційну модель фахової підготовки здобувачів вищої педагогічної освіти хореографічного профілю на засадах компетентнісного підходу.

Виклад основного матеріалу дослідження. Ключовим завданням компетентнісного підходу у вищій освіті $\epsilon$ формування професійної компетентності випускника. Закон України "Про вищу освіту” поняття “компетентність” трактує як “здатність особи успішно соціалізуватися, навчатися, провадити професійну діяльність, яка виникає на основі динамічної комбінації знань, умінь, навичок, способів мислення, поглядів, цінностей, інших особистих якостей” [4].

Стандарт вищої освіти визначає такі фахові компетентності, якими повинен володіти випускник закладу вищої освіти зі спеціальності "Хореографія" освітнього ступеня "Бакалавр" фахівець у сфері виконавського мистецтва, балетмейстерської, викладацької, методичної діяльності в сфері початкової, профільної, фахової передвищої мистецької освіти: “1. Усвідомлення ролі культури і мистецтва в розвитку суспільних взаємовідносин. 2. Здатність аналізувати основні етапи, виявляти закономірності історичного розвитку мистецтв, стильові особливості, види і жанри, основні принципи координації історикостильових періодів світової художньої культури. 3. Здатність застосовувати теорію та сучасні практики хореографічного мистецтва, усвідомлення його як специфічного творчого відображення дійсності, проектування художньої реальності в хореографічних образах. 4. Здатність оперувати професійною термінологією в сфері фахової хореографічної діяльності (виконавської, викладацької, балетмейстерської та організаційної). 5. Здатність використовувати широкий спектр міждисциплінарних зв'язків для забезпечення освітнього процесу в початкових, профільних, фахових закладах освіти. 6. Здатність використовувати ірозробляти сучасні інноваційні та освітні технології в галузі культури і мистецтва. 7. Здатність використовувати інтелектуальний потенціал, професійні знання, креативний підхід до розв'язання завдань та вирішення проблем в сфері професійної діяльності. 8. Здатність сприймати новітні концепції, усвідомлювати багатоманітність сучасних танцювальних практик, необхідність їх осмислення та інтегрування в актуальний контекст 3 врахуванням вітчизняної та світової культурної спадщини. 9. Здатність збирати, обробляти, аналізувати, синтезувати та інтерпретувати художню інформацію 3 метою створення хореографічної композиції. 10. Здатність застосовувати традиційні й альтернативні інноваційні технології в процесі створення мистецького проекту, його реалізації та презентації. 11. Здатність здійснювати репетиційну діяльність, ставити та вирішувати професійні завдання, творчо співпрацювати 3 учасниками творчого процесу. 12. Здатність використовувати принципи, методи та засоби педагогіки, сучасні методики організації та 


\section{МОДЕЛЬ ФАХОВОЇПІДГОТОВКИ ВЧИТЕЛІВ ХОРЕОГРАФІІ НАОСНОВІ КОМПЕТЕНТНІСНОГОПДХОДУ}

реалізації освітнього процесу, аналізувати його перебіг та результати в початкових, профільних, фахових закладах освіти. 13. Здатність використовувати традиційні та інноваційні методики для діагностування творчих, рухових (професійних) здібностей, їх розвитку відповідно до вікових, психолого-фізіологічних особливостей суб'єктів освітнього процесу. 14. Здатність забезпечувати високий рівень володіння танцювальними техніками, виконавськими прийомами, застосовувати їх як виражальний засіб. 15. Здатність застосовувати набуті виконавські навички в концертно-сценічній діяльності, підпорядковуючи їх завданням хореографічного проекту. 16. Здатність дотримуватись толерантності у міжособистісних стосунках, етичних і доброчинних взаємовідносин у сфері виробничої діяльності. 17. Здатність враховувати економічні, організаційні та правові аспекти професійної діяльності" [5, 7-9].

Відповідно вимоги, які висуваються до здобувачів вищої освіти хореографічного профілю освітнього ступеня “Бакалавр”, визначають та коригують зміст їх підготовки. Н. Дзюбишина говорить про формування багатофункціональної професійної компетентності, адже хореограф виступає ще й в ролі “педагога-вихователя, який добре орієнтується у психології вихованців та менеджера, який володіє мистецтвом керівництва хореографічним колективом" $[2,152]$.

Представимо процес формування фахової компетентності майбутнього вчителя хореографії у вигляді моделі. Модель є результатом системного проєктування мети, засобів та очікуваних результатів обраного напряму фахової підготовки (рис. 1).

На нашу думку, фахову компетентність майбутніх хореографів, вчителів хореографії можна представити як сукупність таких структурних компонентів: когнітивний (психологопедагогічні та спеціальні предметні знання); ціннісно-мотиваційний (ціннісне ставлення до обраного фаху, до мистецтва, ціннісні установки, мотивація студентів до оволодіння знаннями, уміннями та навиками, мотивація саморозвитку); діяльнісний (вміння й навички студентів, необхідні для організації та ведення професійної діяльності та міжособистісної комунікації).

Відповідно до зазначених компонентів, завданнями формування фахових компетентностей хореографів є формування: системи фахових знань; позитивної мотивації та ціннісного ставлення до професійної діяльності; фахових навиків та умінь, а також художньо-естетичний розвиток, розвиток творчої активності студентів.

Концептуцальним методологічним підходом до фахової підготовки є компетентнісний, однак в освітньому середовищі закладу освіти пов'язаний 3 особистісно зорієнтованим і діяльнісним підходами до навчання, оскільки стосується особистості студента й може бути реалізованим і перевіреним тільки у процесі виконання конкретним студентом певного комплексу дій. Він потребує трансформації змісту освіти, перетворення його з моделі, яка існує об'єктивно, для “всіх” студентів, на суб'єктивні надбання одного студента, які можна виміряти” $[1,9]$.

Процес формування фахової компетентності випускників закладу вищої освіти зі спеціальності “Хореографія", підготовки до професійної взаємодії з учнями, батьками, 3 творчими колективами грунтується на таких принципах:

- відповідності змісту навчального процесу завданням та кінцевим результатам фахової підготовки здобувачів освіти;

- професійно-педагогічної спрямованості навчального процесу;

- систематичності й послідовності;

- зв’язку теорії (пізнання) та практики (переживання);

- творчості та співтворчості у навчанні.

На нашу думку, формуванню фахової компетентності майбутнього вчителя хореографії сприяють певні педагогічні умови, а саме:

1) вироблення у студентів позитивної навчальної мотивації, позитивного емоційного досвіду через стимулювання пізнавальнопошукової активності, вдосконалення виконавської майстерності;

2) реалізація методичного забезпечення процесу фахової підготовки формування компетентностей;

3) забезпечення постійного зворотного зв'язку у вигляді поточного та підсумкового контролю знань, умінь, практичних навичок студентів;

4) формування у студентів потреби в саморозвитку та постійному фаховому вдосконаленні (від фахової підготовки у закладі вищої освіти на всіх рівнях до післядипломного професійного розвитку).

Загальні та фахові компетентності здобувачі вищої освіти першого (бакалаврського) рівня за спеціальністю “Хореографія” набувають шляхом вивчення психолого-педагогічних та профільних дисциплін. До циклу психолого-педагогічних входять: “Педагогіка”, “Педагогічна етика”, "Психологія" тощо. Цикл професійної підготовки включає нормативні та вибіркові навчальні дисципліни, серед них: “Історія хореографічного мистецтва", “Етика та естетика", “Базова хореографічна термінологія", “Мистецтво балетмейстера", “Основи теорії музики”, “Робота 


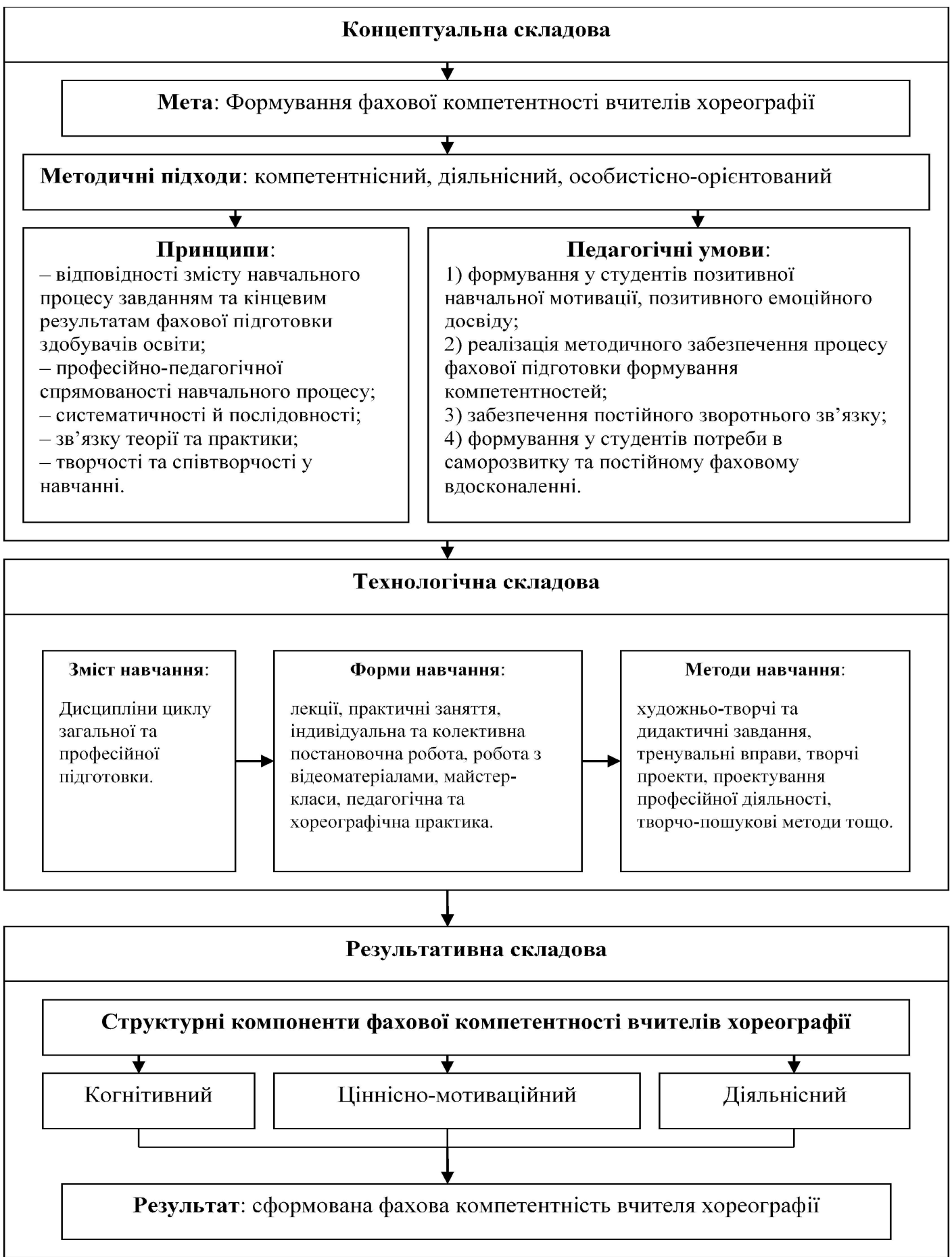

Рис. 1 Організаційна модель фахової підготовки вчителів хореографії на основі компетентнісного підходу

3 хореографічним колективом”, “Теорія і методика народно-сценічного танцю”, “Теорія і методика класичного танцю”, “Теорія і методика українського народного танцю”, “Теорія і методика сучасного бального танцю”, “Підготовка концертних програм та номерів", "Українські народні танці для учнів дошкільного

Молодь і ринок №10 (196), 2021 віку та учнів молодшого шкільного віку" та інші.

Основними формами організації навчальної, художньо-творчої діяльності здобувачів вищої освіти за спеціальністю "Хореографія" є лекції, практичні заняття, індивідуальна та колективна постановочна робота, робота з відеоматеріалами (перегляд і аналіз виступів відомих виконавців, 


\section{МОДЕЛЬ ФАХОВОЇПІГОТОВКИ ВЧИТЕЛІВ ХОРЕОГРАФІЇ НАОСНОВІ КОМПЕТЕНТНІСНОГОПДХОДУ}

танцювальних колективів, майстер-класи з різних танцювальних стилів), проведення майстеркласів, педагогічна та хореографічна практика.

Методами навчання бакалаврів 3 хореографії $\epsilon$ методи фізичного, художнього та творчого розвитку: художньо-творчі та дидактичні завдання, тренувальні вправи, проєктування професійної діяльності, творчо-пошукові методи тощо.

Отже, цілісність та результативність процесу формування фахових компетентностей вчителів хореографії забезпечують відповідні методологічні підходи, дидактичні принципи, педагогічні умови, спеціально підібрані форми і методи роботи зі студентами.

Висновки. Головним результатом компетентнісного підходудофаховоїпідготовкиздобувачів вищої освіти хореографічного профілю освітнього ступеня “Бакалавр" є випускник з високим рівнем професійної компетентності. Відповідно до цього планується навчально-пізнавальна та професійнопрактична діяльність студентів. Відображений у моделі процес формування фахових компетентностей вчителів хореографії виступає інтегративним процесом формування знань, умінь, навичок, досвіду, розвитку особистісних якостей, усвідомлення особистої відповідальність за результати цієї діяльності та необхідність постійного самовдосконалення.

\section{ЛIТЕРАТУРА}

1. Авшенюк, Н., Десятов, Т., Дяченко, Л., Постригач, Н., Пуховська, Л., Сулима, О. Компетентнісний підхід до підготовки педагогів у зарубіжних краӥнах: теорія та практика :монографія. Кіровоград : Імекс-ЛТД. 2014.

2. Дзюбишина, Н. Компетентнісний підхід у процесі підготовки майбутніх хореографів. Оновлення змісту, форм та методів навчання $i$ виховання в закладах освіти , 17, С. 149-153. Відновлено 3 http://nbuv.gov.ua/ UJRN/Ozfm $2017 \quad 17 \quad 42.2017$.

3. Коробченко, А., Головкова, М. Компетентнісний підхід допрофесійної підготовки майбутніхучителів новоїукраїнської школи. Матеріали Всеукраїнської науково-практичної конференції з міжнародною участю "Особистіснопрофесійний розвиток вчителя в умовах реалізаціїКонцепції Нової української школи", Мелітополь, 2018.

4. Про вищу освіту. №1556-VII від 01.07.2014. (редакція від 02.10.2021). URL: https://urst.com.ua/ download act/pro vyshchu osvitu.

5. Стандарт вищої освіти. Перший (бакалаврський рівень) вищої освіти. Ступінь бакалавр. Галузь знань 02 Культура та мистецтво, спеціальність: 024 Хореографія. Відновлено 3 https://mon.gov.ua/storage/ app/media/vishcha-osvita/zatverdzeni $\% 20$ standarty/2020/ 03/024-choreografia-B.pdf 2020.

6. Червонська, Л. Компетентнісний підхід як основа професійної підготовки майбутнього вчителя хореографії в умовах сучасної вищої школи. Матеріали Всеукраїнської науково-практичної конференції 3 міжнародною участю “Особистісно-професійний розвиток вчителя в умовах реалізації Концепції Нової української школи", Мелітополь, 2018.

\section{REFERENCES}

1. Avsheniuk, N., Desiatov, T., Diachenko, L., Postryhach, N., Pukhovska, L., Sulyma, O. (2014). Kompetentnisnyi pidkhid do pidhotovky pedahohiv u zarubizhnykh krainakh: teoriia ta praktyka : monohrafiia [Competence approach to teacher training in foreign countries: theory and practice]. Kirovohrad. [in Ukrainian].

2. Dziubyshyna, N. (2017). Kompetentnisnyi pidkhid u protsesi pidhotovky maibutnikh khoreohrafiv [Competence approach in the process of training future choreographers]. Updates to the content, forms and methods of learning and education in the bookmarks of education. Vol.17, pp.149-153. Available at: http:// nbuv.gov.ua/UJRN/Ozfm $2017 \quad 1742$ [in Ukrainian].

3. Korobchenko, A. \& Holovkova, M. (2018). Kompetentnisnyi pidkhid do profesiinoi pidhotovky maibutnikh uchyteliv novoi ukrainskoi shkoly [Competence approach to professional training of future teachers of the new Ukrainian school]. Materialy Vseukrainskoi naukovo-praktychnoi konferentsii z mizhnarodnoiu uchastiu "Osobystisno-profesiinyi rozvytok vchytelia $v$ umovakh realizatsii Kontseptsii Novoi ukrainskoi shkoly" - Proceedings of the AllUkrainian Scientific and Practical Conference. Personal and professional development of a teacher in the conditions of realization of the Concept of the New Ukrainian school. Melitopol. [in Ukrainian].

4. Pro vyshchu osvitu [About higher education]. №1556-VII vid 01.07.2014. (version from 02.10.2021). Available at: https://urst.com.ua/download_act/ pro_vyshchu_osvitu [in Ukrainian].

5. Standart vyshchoi osvity. Pershyi (bakalavrskyi riven) vyshchoi osvity. Stupin bakalavr. Haluz znan 02 Kultura ta mystetstvo, spetsialnist: 024 Khoreohrafiia (2020). [Standard of higher education. The first (bachelor's level) of higher education. Bachelor's degree. Branch of knowledge 02 Culture and art, specialty: 024 Choreography]. Available at: https://mon.gov.ua/storage/ app/media/vishcha-osvita/zatverdzeni $\% 20$ standarty/2020/ 03/024-choreografia-B.pdf [in Ukrainian].

6. Chervonska, L. (Red.). (2018). Kompetentnisnyi pidkhid yak osnova profesiinoi pidhotovky maibutnoho vchytelia khoreohrafii v umovakh suchasnoi vyshchoi shkoly [Competence approach as a basis of professional training of the future teacher of choreography in the conditions of modern high school]. Materialy Vseukrainskoi naukovo-praktychnoi konferentsii z mizhnarodnoiu uchastiu "Osobystisno-profesiinyi rozvytok vchytelia $v$ umovakh realizatsii Kontseptsii Novoi ukrainskoi shkoly" - Proceedings of the AllUkrainian Scientific and Practical Conference "Personal and professional development of a teacher in the conditions of realization of the Concept of the New Ukrainian school". Melitopol [in Ukrainian].

Стаття надійшла до редакції 08.10.2021 